\title{
XLV. Description of a rotative thermo-magnetical experiment
}

\section{Mr. William Sturgeon}

To cite this article: Mr. William Sturgeon (1824) XLV. Description of a rotative thermomagnetical experiment, Philosophical Magazine Series 1, 63:312, 269-271, DOI:

$10.1080 / 14786442408644505$

To link to this article: http://dx.doi.org/10.1080/14786442408644505

册 Published online: 27 Jul 2009.

Submit your article to this journal \lceil

Џ Article views: 2

Q View related articles $\square$

Citing articles: 1 View citing articles 5 


\section{[ 269 ]}

XLV. Description of a Rotative Thermo-magnetical Lxperimeat. By Mr. Williar Stungeon.

To the Editors of the Philisophical Magazine and Journat.

Gentlemen,

AVING promised in a former paper to communicate to your readers the meibod I have adopted for rotating a thermo-combination by the influence of a central magnet, the following description of the apparatus I have constructed and employ for exhibiting the experiment, with an explanation of its management, will, I humbly hope, be sufticiently plain to be understood.

$\mathrm{NS}$, in the figure, is the magnet; $\widetilde{P} c P$ a piece of platinum wire bent into the form of a semicircle or other convenient curve; $\mathrm{P} s, \mathrm{P} s$ are two pieces of silver wire twisted to the former at the extremities P P. 'The other ends of the silver wires are bent downwards at $s s$; and made quite sharp and smooth at the points. These points descend into the metallic cell $F \mathbf{E}$,

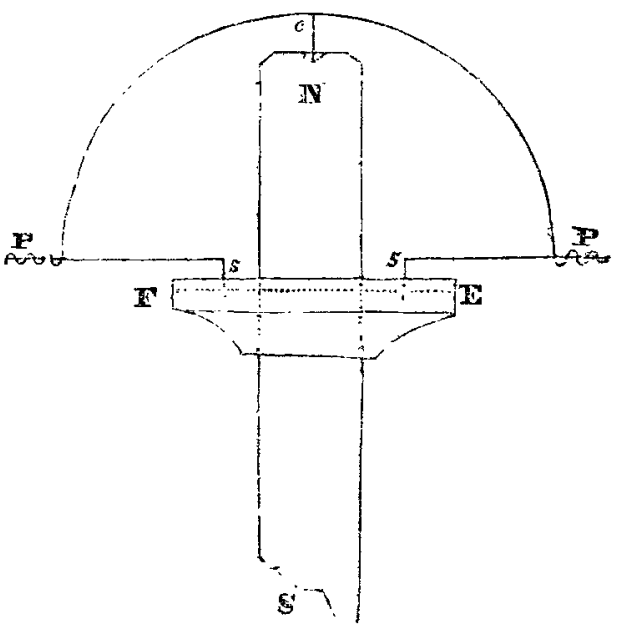
which contains pure quicksilver, with which the points communicate. A descending point $c$ soldered to the platinum wire, forms the pirot or which the moveable part of the machine turns. $A$ small concavity well polished at the bottom is made in the point of the magnet, for the purpose of containing a small globule of mer cury, and likewise for the rotating piwot to work in.

The point $c$ being amalgamated, when it is placed in this globule of nercury, forms a communication with the magnet; and the other part of the magnet which passes through the cell communicates with the mercury in that cell: and the points of the silver wires being immersed in this mereury, the metallic cireuit is thus rendered complete; first, throngh the platinum wire from $\mathrm{P}$ to $c$; thence through the pivot to 
$270 \mathrm{Mr}$. Sturgèon on a rotative thermo-magnetical Experiment.

the top of the magnet, and along that part of the magnet from the top to the quicksilver in the cell F E : and lastly, along the silver wire from the point $s$ to the extremity at $\vec{P}$, where it joins the platinum.

The other part of the wire machine being on the same principle as that described, the platinum arms of this apparatus, when heated by a spirit lamp or otherwise at the extremities PP, are in every respect assimilated to the arms of the rotating cylinder of Ampere; for the electric fluid is transmitted in the same direction through both arms of the apparatus; and hence the rotating tendency is constant round a central magnet; and not impulsive, as in other rotations with an external magnet.

The moveable part of this machine (which is the platinum and silver wires only) will rotate with a facility proportioned to the delicacy of the suspension, the difference of temperature of the parts $\mathrm{P}$ and $c$ of each arm, the power of the magnet, and the dexterity of the experiments. And I must here warn the reader, that this last requisite is not the least to ensure success in the experiment; for had I not been satisfied that the apparatus was constructed upon principle, I probably might not have persevered sufficiently to attain my object. However, a slight modification of the apparatus considerably facilitates the experiment, and renders it more permanent and beautiful.

A circle of lamps are placed on a stage of the same figure, in such a manner that they may coincide with the periphery of the circle described by the points $\mathrm{P} P$ of the wire part of the machine, so that the latter may constantly be kept at nearly the same temperature in every part of their revolution. And the shoulder of those arms, or that part of the platinum wire to which the pivot $c$ is soldered, is kept at as low a temperature as possible by means of ether or other cooling liquid.

If instead of lamps a circular flame of ignited hydrogen be substituted, and regulated by a stop-cock, this part of the apparatus may perhaps be considered at its acme of perfection.

Another improvement is by having a conducting wire from the pivot $c$ to the metallic cell $\mathrm{FE}$, in the same manner as the conducting wire of the copper part of M. Ampere's rotating cylinders; through the upper part of this conducting wire passes a screw with a milled head, made into the form of a cup. The pivot $c$ runs in this cup, at the bottom of which is a small globule of mercury, for the better ensuring the contact. The cup is then filled up with ether, and may be supplied during the experiment in proportion to the evaporation. 
The lower end of this screw rests in the hole in the top of the magnet; and by turning the milled head to the right or left, the points $s s$ of the silver wires may be heightened or lowered at pleasure; and consequently their contact with the mercury in the cell FE may be regulated to the greatest nicety; the attainment of which was the only embarrassment I had to encounter with the original apparatus. However, by means of this improvement my anticipations were soon agreeably realized by witnessing the first thermo rotation ever produced by the influence of a central magnet.

I must here beg leave to observe, that the only attempt I ever heard of (and the only one perhaps on record) was with the apparatus of Professor Cumming, and a similar attempt by Professor Barlow with a combination upon the same principles.

The latter gentleman, however, has candidly confessed the failure of the experiment, and sufficiently accounted for the inefficacy of the apparatus upon the principle of its construction,

$$
\text { I am, gentlemen, yours respectfully, }
$$

Artillery Place, Woolwich.

Wm. Sturgeon.

P.S.-April 13. I have since succeeded in forming a sphere of galvanized wires, to rotate by the influence of both poles of an internal magnet.

This experiment was suggested on reading the late Dr. Halley on the theory of the earth; and although it may not be considered as a proof of that philosopher's notion of terrestrial magnetic variation, yet perhaps it may tend in some measure to strengthen the hypothesis. A description of the apparatus shall be the subject of another paper.

W. S.

XLVI. On Parallel Straight Lines. By John Walsh, Esq.**

$\mathrm{N}$ this paper my object is not to terminate a controversy, but to render service to science, to banish from it, as far as this is in my power, all fallacious reasoning about an elementary principle which is the basis of all mathematical science. I must observe again, that the difficulty encountered in the theory of parallels, arises out of the nature of things. It arises from this, that space has no limit. Can the geometer imagine space beyond which there is no space? Can

* Communicated by the Author. 